\title{
Model-based prediction of maximum pool size in the ribbon synapse
}

\author{
Caitlyn M Parmelee ${ }^{1 *}$, Matthew Van Hook ${ }^{2}$, Wallace B Thoreson ${ }^{2,3}$, Carina Curto ${ }^{4}$ \\ From 24th Annual Computational Neuroscience Meeting: CNS*2015 \\ Prague, Czech Republic. 18-23 July 2015
}

The synaptic ribbon is a specialized structure in photoreceptor neurons that tethers vesicles prior to release (Figure 1A). When a cell is stimulated, vesicles are released from the ribbon and later replenished from the population of mobile vesicles in the synaptic terminal. A train of depolarizing pulses causes the ribbon to alternate between periods of release (lasting $\Delta t=25 \mathrm{~ms}$ ) and replenishment (lasting $\mathrm{T}=50 \mathrm{~ms}$ ), which occur on estimated timescales of $\tau_{\mathrm{r}}=5 \mathrm{~ms}$ (for release) and $\tau_{\mathrm{a}}=815 \mathrm{~ms}$ (for replenishment). After the first few pulses, the system approaches a limit cycle, and the amount of vesicles released on each pulse converges to a limiting value, $R$ (Figure 1B). This can be used to determine the maximum available pool size on the ribbon, A. The standard method for estimating $\mathrm{A}$ is to measure the rate of replenishment in the limit, and then back-extrapolate from the cumulative release plot to obtain the available pool size at the start of the pulse train [1]. When comparing pulse trains of different strengths, this method yields substantially different values for A, a somewhat paradoxical result. Back-extrapolation assumes, however, that the replenishment rate is constant, even though it is thought to be proportional to the available space on the ribbon [2].

We developed a model-based approach to estimate A from the limiting release $\mathrm{R}$. We modeled the rate of release (resp. replenishment) to simply be proportional to the number of vesicles on the ribbon (resp. vacant ribbon sites), and using the measured timescale $\tau_{\mathrm{r}}$ (resp. $\tau_{\mathrm{a}}$ ). By solving the alternating differential equations, we derived a recurrence relation for the release during each pulse, $R_{i}$, which we then solved to obtain a closed form expression for $R_{i}$ and the limiting release R. Specifically, we found that $\mathrm{A}=\mathrm{cR}$, where $\mathrm{c}$ is a function of $\tau_{\mathrm{r}}, \tau_{\mathrm{a}}, \Delta \mathrm{t}$, $\mathrm{T}$, and $\mathrm{p}$, with $\mathrm{p}$ a release constant that captures the stimulus dependence of release probabilities, and can be estimated from the first release, $R_{1}$. In contrast to the

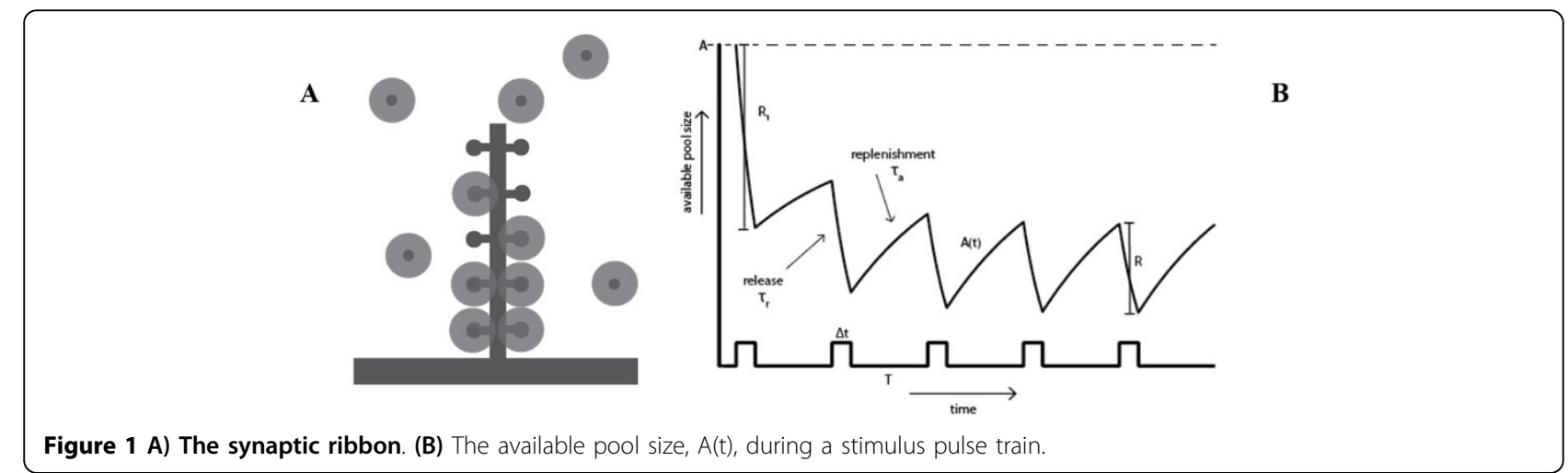

\footnotetext{
* Correspondence: s-cparmel1@math.unl.edu

'Department of Mathematics, University of Nebraska-Lincoln, Lincoln, NE 68588, USA

Full list of author information is available at the end of the article
} 
Table 1 Maximum pool size predictions from pulse train data

\begin{tabular}{lll}
\hline Stimulus & Estimate for A, from back-extrapolation & Estimate for A, from the model \\
\hline$-10 \mathrm{mV}$ (stronger) & $-136.8794 \mathrm{pA}$ & $-131.6858 \mathrm{pA}$ \\
$-30 \mathrm{mV}$ (weaker) & $-75.1020 \mathrm{pA}$ & $-133.6100 \mathrm{pA}$ \\
\hline
\end{tabular}

back-extrapolation method, our model-based estimate for A was similar across stimulus types (Table 1), while $\mathrm{p}$ was much smaller for the weaker stimulus. This suggests that available pool size does not change with stimulus strength; instead, differences in release result from changes in release probability.

\section{Authors' details}

'Department of Mathematics, University of Nebraska-Lincoln, Lincoln, NE 68588, USA. ${ }^{2}$ Department of Ophthalmology and Visual Sciences, University of Nebraska Medical Center, Omaha, NE 68198, USA. ${ }^{3}$ Department of Pharmacology and Experimental Neuroscience, University of Nebraska Medical Center, Omaha, NE 68198, USA. ${ }^{4}$ Department of Mathematics, The Pennsylvania State University, University Park, PA, 16802, USA.

Published: 18 December 2015

\section{References}

1. Sakaba T, Schneggenburger R, Neher E: Estimation of quantal parameters at the calyx of Held synapse. Neurosci Res 2002, 44(4):343-356.

2. Van Hook MJ, Parmelee CM, Chen M, Cork KM, Curto C, Thoreson WB: Calmodulin enhances ribbon replenishment and shapes filtering of synaptic transmission by cone photoreceptors. J Gen Physiol 2014, 144(5):357-378.

doi:10.1186/1471-2202-16-S1-P41

Cite this article as: Parmelee et al: Model-based prediction of maximum pool size in the ribbon synapse. BMC Neuroscience 2015 16(Suppl 1):P41.

Submit your next manuscript to BioMed Central and take full advantage of:

- Convenient online submission

- Thorough peer review

- No space constraints or color figure charges

- Immediate publication on acceptance

- Inclusion in PubMed, CAS, Scopus and Google Scholar

- Research which is freely available for redistribution

Submit your manuscript at www.biomedcentral.com/submit
C Biomed Central 